\title{
The content and composition of organic matter in bottom sediments of the Rybnik reservoir - preliminary studies
}

\author{
Agnieszka Baran ${ }^{1}$, Monika Mierzwa-Hersztek ${ }^{1}$, Krzysztof Gondek ${ }^{1}$, \\ Magdalena Szara ${ }^{1}$, Marek Tarnawski ${ }^{2}$ \\ ${ }^{1}$ University of Agriculture in Krakow, Department of Agricultural and Environmental Chemistry; \\ al.A. Mickiewicza 21,31-120 Krakow, Poland; e-mail: Agnieszka.Baran@ur.krakow.pl,monika.mierzwa@urk.edu.pl, \\ krzysztof.gondek@urk.edu.pl,magdalena.szara@student.ukr.edu.pl \\ ${ }^{2}$ University of Agriculture in Krakow, Department of Hydraulic Engineering and Geotechnics; \\ al. A. Mickiewicza 24/28,30-059 Krakow, Poland; e-mail: marek.tarnawski@urk.edu.pl
}

(C) 2018 Authors. This is an open access publication, which can be used, distributed and reproduced in any medium according to the Creative Commons CC-BY 4.0 License requiring that the original work has been properly cited.

Received: 11 December 2017; accepted: 20 June 2018

\begin{abstract}
Organic matter has important influences on the fate of environmental pollution in water dam reservoirs. The aim of the studies was to assess content of organic matter fractions in Rybnik reservoir bottom sediments, and to determine their influence on the content of heavy metals and PAHs. In three sediment samples, the content of C organic (Corg), C extracted (Cex), C humic acid (Cha), C fulvic acid (Cfa) and C non-hydrolyzed (Cnh), buffer capacity, and content of heavy metals and PAHs was analyzed. We found the highest content of Corg, Cex, Cha, Cfa and Cnh in sample 3 (the outlet, near the dam), while the lowest content was found in sample 2 (middle). The fraction of Cnh was dominant in sediment sample 3 (outlet, near dam) and 1 (inlet), whereas the fraction of Cha dominated in sample 2 (middle). Rybnik bottom sediments are characterized by their high buffer capacities (samples 3,1 ) shaped among others by the high content of organic matter. The high organic matter content in samples 3 (outlet) and 1 (inlet) and also high total contents of heavy metals and $\mathrm{PAH}_{\mathrm{S}}$ in these sediments demonstrate that these pollutants have a strong affinity for organic matter in the sediments. Moreover, the highest mobility of metals, from sample 2 (middle), is connected with the low content of organic matter substances and the low buffer capacities of sediments.
\end{abstract}

Keyword: bottom sediments, organic matter, buffer capacity, pollutions

\section{INTRODUCTION}

Bottom sediment in reservoirs originates from the sedimentation of particulate matter delivered by a river, slope runoff and the precipitation of detritus. A wide variety of contaminants, including heavy metals, PAHs, PCB, dioxins and chloroorganic pesticides, are discharged into the aquatic environment and accumulate in sediments (Boháček et al. 2003, Szarek-Gwiazda 2014,
Urbaniak et al. 2015, Baran et al. 2016, 2017, Mamontova et al. 2016). The contents of the above substances in sediments may be three times higher than those found in water, and although certain chemicals are strongly sorbed to sediment, they may still be available for biota, thus causing a risk to benthic organisms (Tuikka et al. 2011, Bojakowska \& Krasuska 2014). Organic matter is one of the most important components of bottom sediments, determining their physical, chemical 
and biological properties, and is mainly responsible for the sorption properties of bottom sediments. Moreover, since organic matter in bottom sediment is an accumulating medium, it can provide important information about the pollution level of a water body, including pollution by heavy metals and organic pollutants (PAHs, PCB, dioxins) (Boháček et al. 2003). In the sediments, humic substances account for about $60-70 \%$ of the total organic matter and are recognized as the most persistent storage of sedimentary organic carbon (Hou et al. 2014). Humic substances have an important influence on the sorption, distributions, transport and fate of environmental pollution (Oleszczuk 2007, Mengchang et al. 2008, Giovanela et al. 2010, Morales et. al. 2012, Ukalska-Jurga et al. 2015).

The aims of the studies were as follows: to assess the content of organic matter fractions in bottom sediment collected from the Rybnik reservoir, and to determine their impact on the content of heavy metals and PAHs.

\section{METHODS}

The Rybnik dam reservoir is one of the most important reservoirs in the Silesian area and it is the only anthropogenic-type reservoir in Poland (Fig. 1). The Rybnik reservoir is situated on the Ruda River, impounding a catchment with an area of $308 \mathrm{~km}^{2}$, the long side of the reservoir is $7 \mathrm{~km}$ long and its initial capacity was $25.8 \mathrm{mln} \mathrm{m}^{3}$ in the impoundment area, together with lateral impoundments of 555 ha (Baran et al. 2016). The functions of the reservoir include a source of cooling water for the Rybnik Power Plant JSC, flood control, recreation and waterfowl habitat.

The bottom sediment samples were collected using an Ekman sampler from three characteristic set locations: 1 - inlet (backwater station), 2 - middle and 3 - outlet (close to the dam) (Fig. 1). In order to average the collected material, the samples were collected from five points within a radius of 5-8 meters from the appointed location. The top layer of the sediment was collected from $0-15 \mathrm{~cm}$. All sediment samples were refrigerated until analyzed.

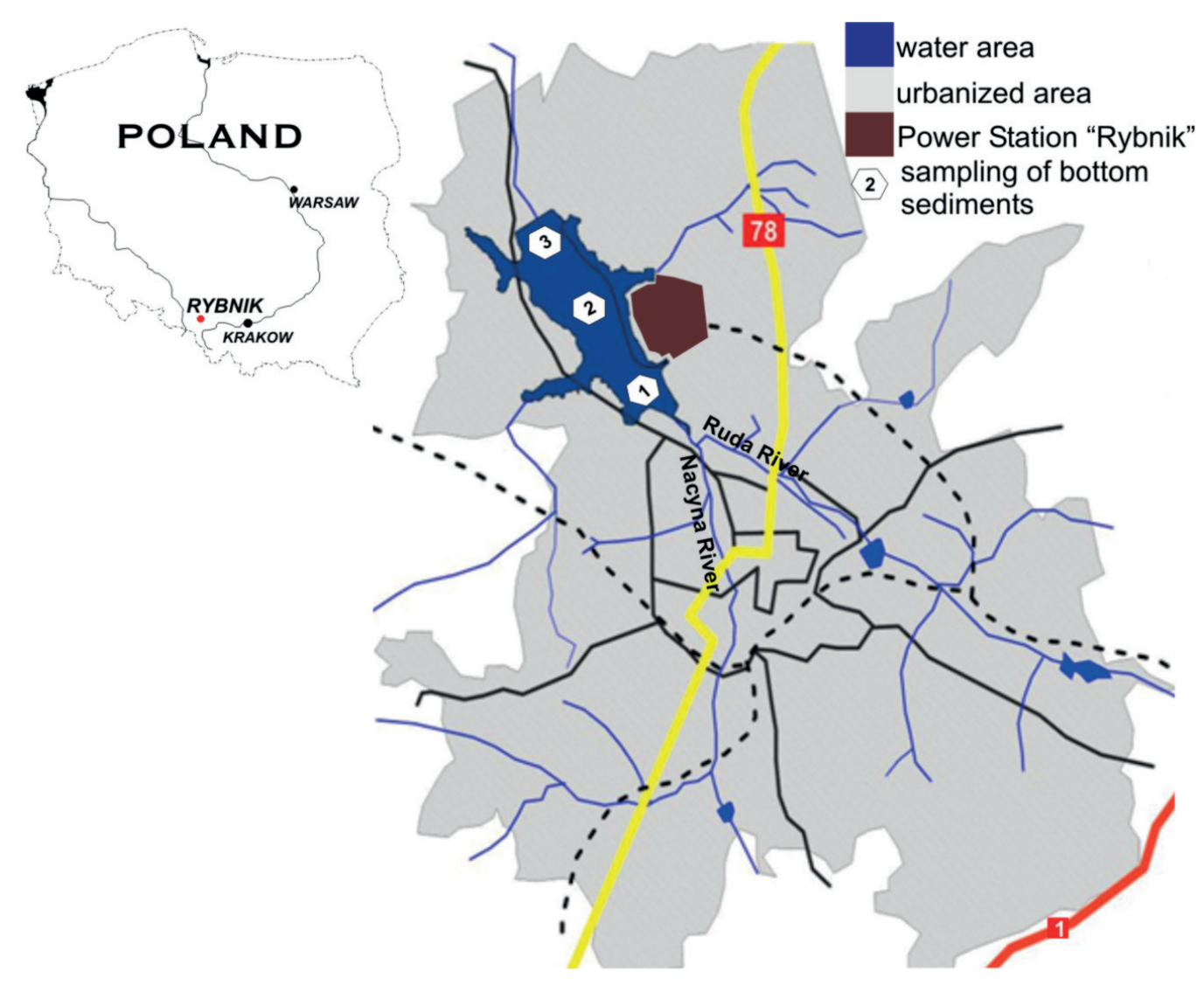

Fig. 1. Localization of Rybnik reservoir 
The organic carbon content, after mineralization in potassium dichromate (VI), was assessed by means of Tiurin's method. The content of humus compounds was extracted from sediments by a solution mixture of $0.1 \mathrm{~mol} \cdot \mathrm{dm}^{-3} \mathrm{Na}_{4} \mathrm{P}_{2} \mathrm{O}_{7}+$ $+0.1 \mathrm{~mol} \cdot \mathrm{dm}^{-3} \mathrm{NaOH}$ (Kononowa 1968). The carbon of humic acids (Cha) was isolated in an extract of sodium pyrophosphate and sodium base, whereas the carbon of fulvic acids (Cfa) was calculated from the difference between the amount of carbon in the extract (Cex) and the amount of humic acid carbon (Cha) contained in the extract. The extraction residue a non-hydrolyzing carbon (Cnh) was computed from the difference between the organic carbon content $(\mathrm{C}$ org) and the amount of carbon in the extract (Cex) (Gondek \& Kopeć 2006, Gondek \& Mierzwa-Hersztek 2014). The buffer capacity of sediments, with an increase in acidity, was determined by the Arrhenius method (Baran et al. 2011a). In the sediment, the buffer was assessed after adding to the sediment an appropriate amount of $0.1 \mathrm{~mol} \cdot \mathrm{dm}^{-3} \mathrm{HCl}$ solution $\left(2,4,6,8\right.$ and $\left.10 \mathrm{~cm}^{3}\right)$ and a subsequent measurement of changes in the $\mathrm{pH}$ value. This method consists in plotting the curves of the buffer on the basis of measurements of the $\mathrm{pH}$ series of the weighed amounts of bottom sediment suspended in an acid solution of $0.1 \mathrm{~mol} \cdot \mathrm{dm}^{-3} \mathrm{HCl}\left(0-10 \mathrm{~cm}^{3}\right)$ at a solid phase/solution ratio of 1:10. After $24 \mathrm{~h}$, the $\mathrm{pH}$ was measured. The total contents of heavy metals ( $\mathrm{Zn}, \mathrm{Cu}, \mathrm{Ni}, \mathrm{Cr}, \mathrm{Pb}$ and $\mathrm{Cd}$ ) and their forms soluble in $1 \mathrm{~mol} \cdot \mathrm{dm}^{-3} \mathrm{HCl}$ were assessed in airdried samples of the sediments. Pseudo total metal contents in the sediments were assessed after dry and hot degistation in a mixture of $\mathrm{HNO}_{3}$ and $\mathrm{HClO}_{3}$ acids (3:2). The extraction of metal from the sediments was conducted using the static method through a single shaking of sediment samples with $1 \mathrm{~mol} \cdot \mathrm{dm}^{-3} \mathrm{HCl}$ at the sediment to a solution ratio of 1:10 and an extraction time of $1 \mathrm{~h}$. (Baran et al. 2011a, 2011b). The metal concentrations in the obtained solutions and extracts were assessed using the ICP-OES method with the use of Optima 7300 DV PerkinElmer. The reference material CRM 16-05 (trace elements) was used for the accuracy of the analyses. The percentage of recovery was between: $95-112 \%$ for $\mathrm{Zn}$; $81-98 \%$ for $\mathrm{Cu}$; 98-114\% for $\mathrm{Pb}$; $88-99 \%$ for $\mathrm{Cr} ; 78-98 \%$ for $\mathrm{Cd}$ and $96-107 \%$ for $\mathrm{Ni}$.
Concentrations of the 9 PAHs (naphthalene (NAP), fluorene (FLN), phenanthrene (PHE), anthracene (ANT), fluoranthene (FLT), pyrene (PYR), benzo(a)anthracene BAA, chrysene CHR, benzo(a)pyrene (BAP)) were determined by gas chromatography-mass spectrometry on a Varian GC/MS/MS 4000 equipped with an ion trap (Baran et al. 2017). The recoveries for PAHs were: 98.5\% (NAP); 86.4\% FLN; 89\% (PHE); 88\% (ANT); 90\% (FLT); 85\% (PYR); 84\% (BAA); 80\% (CHR); $83 \%$ (BAP). Moreover, the limit of detection (LOD) was $2 \mu \mathrm{g} \cdot \mathrm{kg}^{-1} \mathrm{DM}$ and the limit of quantification (LOQ) was $6 \mu \mathrm{g} \cdot \mathrm{kg}^{-1} \mathrm{DM}$.

Statistical computations comprised the following basic parameters: arithmetic mean, standard deviation and correlation coefficient. The statistical analysis was conducted using the Statistica 12.0 software.

\section{RESULT}

The content and quality of organic matter is an important characteristic of bottom sediments from the perspective of the physicochemical conditions at the reservoir bottom. The carbon content in the fractions of organic matter in surface sediments was presented in Table 1. Generally, the highest content of $\mathrm{C}$ organic, $\mathrm{C}$ extracted, $\mathrm{Cfa}$ and $\mathrm{Cnh}$ was found in sample 3 (outlet), while the lowest content was found in sample 2 (middle). However, the highest content of Cha was observed in bottom sediments from sample 3 (outlet) and the lowest content in sample 1 (inlet). The content of C extracted accounted for 32 (sample outlet - 3) - 79\% (sample middle - 2), whereas the $\mathrm{C}$ non-hydrolysing (Cnh) accounted for about 21 (sample middle -2 ) $-68 \%$ (samples 3 ) of the total organic C in the sediment samples. The contents of Cha, Cfa and $\mathrm{Cnh}$ in the sediment samples were detected in the range of $0.96-5.50 \mathrm{~g} \cdot \mathrm{kg}^{-1}$ (Cha), $1.21-5.85 \mathrm{~g} \cdot \mathrm{kg}^{-1}$ (Cfa) and $0.72-24.04 \mathrm{~g} \cdot \mathrm{kg}^{-1}(\mathrm{Cnh})$. The fraction of Cnh dominated in samples 3 and 1 , whereas the fraction of Cha dominated in sample 2 (Tab. 1). In samples 3 and 1 , the fraction of $\mathrm{Cnh}$ was about $68 \%$ and $60 \%$, the fraction of Cfa was about $17 \%$ and $29 \%$, and the fraction of Cha was about $16 \%$ and $11 \%$ of the total organic carbon. In the middle sample, the fraction of humic substances accounted for about 43\% (Cha), 36\% (Cfa) and 21\% (Cnh) of the total organic carbon (Tab. 1). 
Table 1

Carbon content in the fractions of organic matter in the bottom sediments

\begin{tabular}{|c|c|c|c|c|c|c|}
\hline \multirow{2}{*}{$\begin{array}{c}\text { Bottom } \\
\text { sediment }\end{array}$} & C organic & C extracted & $\begin{array}{c}\text { C humic acid } \\
\text { (Cha) }\end{array}$ & $\begin{array}{c}\text { C fulvic acid } \\
\text { (Cfa) }\end{array}$ & \multirow{2}{*}{ Cha/Cfa } & $\begin{array}{c}\text { C non-hydrolyzing } \\
\text { (Cnh) }\end{array}$ \\
\cline { 2 - 6 } & \multicolumn{7}{|c|}{ [g.kg d.m.] } & & [g.kg d.m.] \\
\hline \multirow{2}{*}{ Inlet -1} & 8.98 & 3.57 & 0.96 & 2.61 & 0.37 & 5.42 \\
& \pm 0.32 & \pm 0.26 & \pm 0.08 & \pm 0.34 & \pm 0.08 & \pm 0.58 \\
\hline \multirow{2}{*}{ Middle - 2} & 3.36 & 2.65 & 1.43 & 1.21 & 1.18 & 0.72 \\
& \pm 0.02 & \pm 0.17 & \pm 0.17 & \pm 0.004 & \pm 0.14 & \pm 0.17 \\
\hline \multirow{2}{*}{ Outlet -3} & 35.38 & 11.35 & 5.50 & 5.85 & 0.95 & 24.04 \\
& \pm 2.04 & \pm 0.02 & \pm 0.51 & \pm 0.507 & \pm 0.17 & \pm 2.04 \\
\hline
\end{tabular}

The ratio of Cha/Cfa is used as an indicator of humus quality (Hou et al. 2014). The ratio of Cha/Cfa ranged between 0.37 (sample 1) - 1.18 (sample 2). Generally, the higher value of Cha/Cfa indicated a relatively good humus quality ( $\mathrm{Hu}$ et al. 2014).

Buffer is the sediment's ability to counteract changes of its $\mathrm{pH}$ under the influence of acids or bases (Baran et. al 2011a, Szarek-Gwiazda 2014). An influence of a decreasing $\mathrm{pH}$ on the release of heavy metals from the sediment was found in dam reservoirs (López et al. 2010). The data presented in Figure 2 show that the Rybnik bottom sediment has high buffering properties, especially in samples 3 and 1 . A decrease in the $\mathrm{pH}$ value in the sediment samples was between $7-13 \%$ (sample 3),
$0.5-16 \%$ (sample 1) and 5-26\% (sample 2). In the studies of Szarek-Gwiazda (2014) and Baran et al. (2011a), high buffer capacities in the sediments of some Carpathian dam reservoirs were also found. However, the buffer capacity of these reservoir sediments was mainly associated with clay, carbonate and calcium content.

Our previous studies have shown that bottom sediments from the Rybnik reservoir are characterized by a greater sand fraction than clay and silt (Baran et al. 2016). Therefore, we suppose that organic matter is likely to be an important factor influencing the buffer capacity of sediments. It should be mentioned that the sorption capabilities of humus compounds are several times higher than the sorption capacity of mineral compounds.

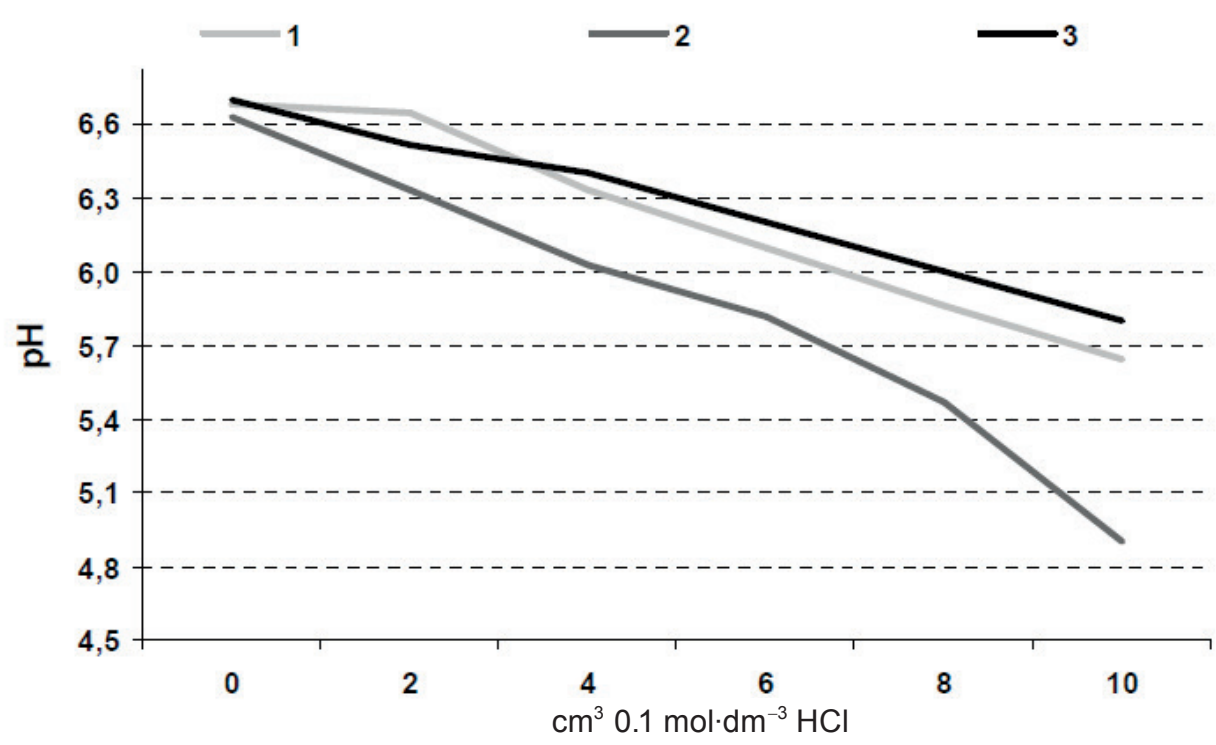

Fig. 2. Buffer capacity of the bottom sediments: 1 - inlet, 2 - middle, 3 - outlet 
This property makes it possible for humus substances to react with different pollutants, creating permanent bonds (Oleszczuk 2007a, 2007b, Klimkowicz-Pawlas 2009, Maliszewska-Kordybach et al. 2010). Moreover, we found that a higher organic matter content tends to increase the buffering capacity of sediments (Fig. 2).

The total content of heavy metals in the bottom sediment is presented in Table 2. The highest total content of $\mathrm{Zn}$ and $\mathrm{Ni}$ was found in sample 1 (inlet); $\mathrm{Cu}, \mathrm{Cd}$ in sample 2 (middle); and $\mathrm{Cr}, \mathrm{Pb}$ in sample 3 (outlet). The content of heavy metals in the bottom sediment formed the following order $\mathrm{Zn}>\mathrm{Cu}>\mathrm{Cr}>\mathrm{Pb}>\mathrm{Ni}>\mathrm{Cd}$ (inlet); $\mathrm{Zn}>\mathrm{Cu}>\mathrm{Pb} \approx$ $\approx \mathrm{Cr}>\mathrm{Ni}>\mathrm{Cd}$ (middle); $\mathrm{Zn}>\mathrm{Cr}>\mathrm{Pb}>\mathrm{Cu}>\mathrm{Ni}>\mathrm{Cd}$ (outlet), and concerning the coefficient of variation (CV\%), respectively, $\mathrm{Cu}(90 \%)>\mathrm{Cr}(40 \%)>$ $>\mathrm{Pb}(28 \%)>\mathrm{Cd}(18 \%)>\mathrm{Ni}(10 \%)>\mathrm{Zn}(6 \%)$.

Table 2

Content of heavy metals in the bottom sediment $\left[\mathrm{mg} \cdot \mathrm{kg}^{-1} \mathrm{~d} . \mathrm{m}\right.$.]

\begin{tabular}{|l|c|c|c|c|c|c|}
\hline \multirow{2}{*}{$\begin{array}{c}\text { Bottom } \\
\text { sediment }\end{array}$} & Zn & Cu & Ni & Cr & Pb & Cd \\
\cline { 2 - 7 } & \multicolumn{7}{|c|}{$\left[\mathbf{1}\right.$ mol·d $\left.\mathbf{d m}^{-3} \mathbf{H C l}\right]$} \\
\hline \multirow{2}{*}{ Inlet - 1 } & 705 & 79 & 27 & 40 & 52 & 5.7 \\
& \pm 75 & \pm 1.5 & \pm 0.1 & \pm 0.4 & \pm 3 & \pm 0.1 \\
\hline \multirow{2}{*}{ Middle - 2 } & 680 & 409 & 25 & 35 & 55 & 8.7 \\
& \pm 31 & \pm 30 & \pm 1 & \pm 1 & \pm 1 & \pm 0.5 \\
\hline \multirow{2}{*}{ Outlet - 3 } & 569 & 51 & 14 & 83 & 90 & 2.0 \\
& \pm 21 & \pm 25 & \pm 3 & \pm 5 & \pm 10 & \pm 0.3 \\
\hline Sample & \multicolumn{7}{|c|}{ Pseudo-total metal content } \\
sediment & 950 & 130 & 42 & 120 & 64 & 9.6 \\
\hline \multirow{2}{*}{ Inlet - 1 } & \pm 30 & \pm 3 & \pm 1 & \pm 3 & \pm 2 & \pm 0.2 \\
\hline \multirow{2}{*}{ Middle - 2 } & 821 & 527 & 37 & 61 & 62 & 12.2 \\
& \pm 65 & \pm 58 & \pm 2 & \pm 5 & \pm 2 & \pm 0.5 \\
\hline \multirow{2}{*}{ Outlet - 3 } & 907 & 84 & 34 & 162 & 108 & 3.3 \\
& \pm 14 & \pm 3 & \pm 2 & \pm 9 & \pm 4 & \pm 0.7 \\
\hline TEC & 121 & 32 & 22.7 & 43.3 & 34 & 0.9 \\
PEC & 459 & 149 & 48.6 & 111 & 128 & 4.9 \\
\hline
\end{tabular}

Besides knowledge about the total heavy metal content in the sediment, also knowing their soluble forms is incredibly useful because of their possible mobilization from the solid phase and penetration into the environment. The content of the solubility forms of metals depended primarily on their total content in the bottom sediment. This was true for $\mathrm{Zn}, \mathrm{Ni}, \mathrm{Cu}, \mathrm{Cd}, \mathrm{Cr}$ and $\mathrm{Pb}$ of which the highest contents of solubility forms were registered in the sediments collected from sampling point $1(\mathrm{Zn}, \mathrm{Ni})$, point $2(\mathrm{Cu}, \mathrm{Cd})$ and point 3 $(\mathrm{Cr}, \mathrm{Pb})($ Table 2$)$. The solubility in $1 \mathrm{~mol} \cdot \mathrm{dm}^{-3} \mathrm{HCl}$, depending on the sampling place, was very high and ranged: $63-83 \%(\mathrm{Zn}), 61-72 \%(\mathrm{Cu}), \mathrm{f} 44-69 \%$ $(\mathrm{Ni}), 34-57 \%(\mathrm{Cr}), 80-87 \%(\mathrm{~Pb})$ and from $37 \%$ to almost $72 \%(\mathrm{Cd})$ in comparison to their total content (Fig. 3). The lowest average solubility in $1 \mathrm{~mol} \cdot \mathrm{dm}^{-3} \mathrm{HCl}$ was characterized by $\mathrm{Cr}$, followed by $\mathrm{Cd}<\mathrm{Ni}<\mathrm{Cu}<\mathrm{Zn}<\mathrm{Pb}$. The highest solubility of metals was found in sample 2 (middle), and the lowest in sample 1 (inlet) (Cr) and 3 (outlet) (Zn, $\mathrm{Cu}, \mathrm{Ni}, \mathrm{Pb}, \mathrm{Cd}$ ) (Fig. 3).

According to the authors, the low organic matter content and low buffer capacities of bottom sediments from sample 2 (middle) may affect the highest mobility of metals. Heavy metals in sediments may exist in different chemical forms or in terms of their ways of binding. In unpolluted sediments, metals are mainly bound to silicates and primary minerals, forming relatively immobile forms, whereas in polluted ones, metals are generally more mobile and bound to other sediment phases. In environmental studies, the determination of the different ways of binding gives more information on trace metal mobility, as well as on their availability or toxicity, in comparison with the total element content. The presented studies used acid extraction to assess the mobility of metals. The obtained results allow the determination of potential metal solubility. Metals soluble in $1 \mathrm{~mol} \cdot \mathrm{dm}^{-3} \mathrm{HCl}$ allow the estimation of their mobilization as a result of the acidification of the environment in which they occur. Generally, metals extracted with the use of hydrochloric acid were bound to exchangeable carbonate and Fe/Mn oxide fractions as well as to organic matter, but this does not reflect their actual hazard to organisms (Baran et. al. 2011b).

The contents of PAHs in the sediment samples are given in Table 3. Generally, the highest content of individual PAHs (without CHR) and $\Sigma_{9} \mathrm{PAHs}$ was found in sample 3 near the dam; the lowest in sample middle - 2 (without FLN, BAP). From the PAHs, in all samples, FLT was represented most strongly - its percentage share in the $\sum_{9} \mathrm{PAHs}$ amounted to $32 \%$ (middle - 2), 29\% (inlet - 1) and $27 \%$ (outlet -3 ). The second in line was PYR, with the percentage share in the $\sum_{9} \mathrm{PAHs}$ between $20 \%$ (inlet - 1) and 24\% (middle - 2) (Fig. 4). 


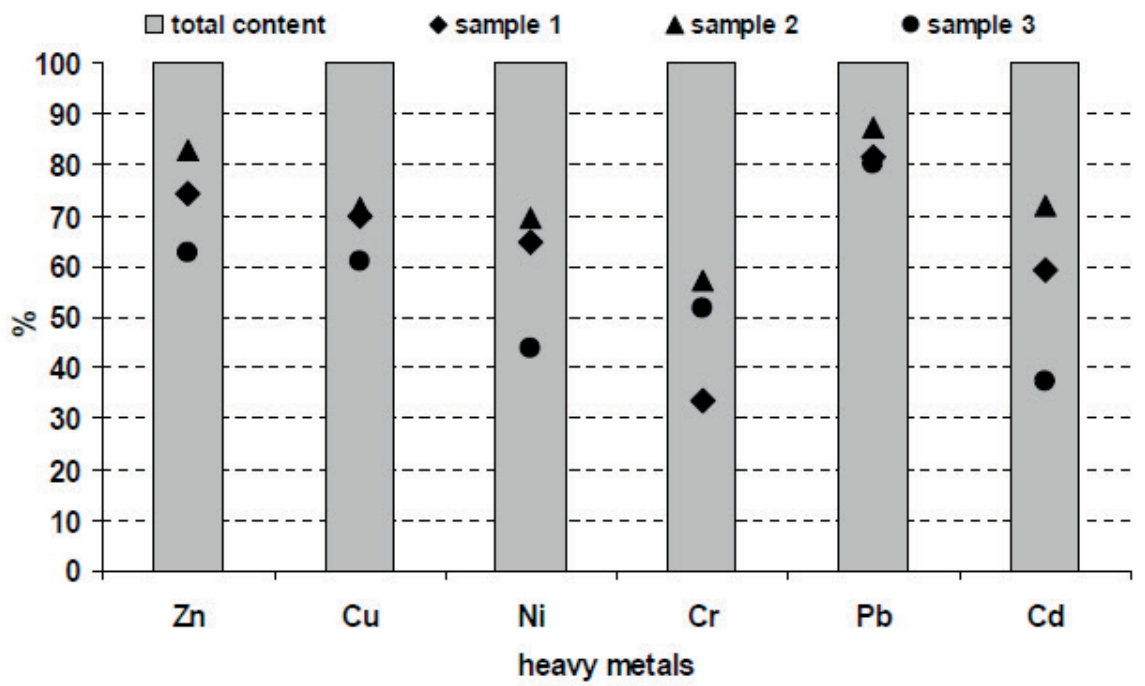

Fig. 3. Percentage share of available forms $\left[1 \mathrm{~mol} \cdot \mathrm{dm}^{-3} \mathrm{HCl}\right]$ of heavy metals in their total contents in bottom sediment

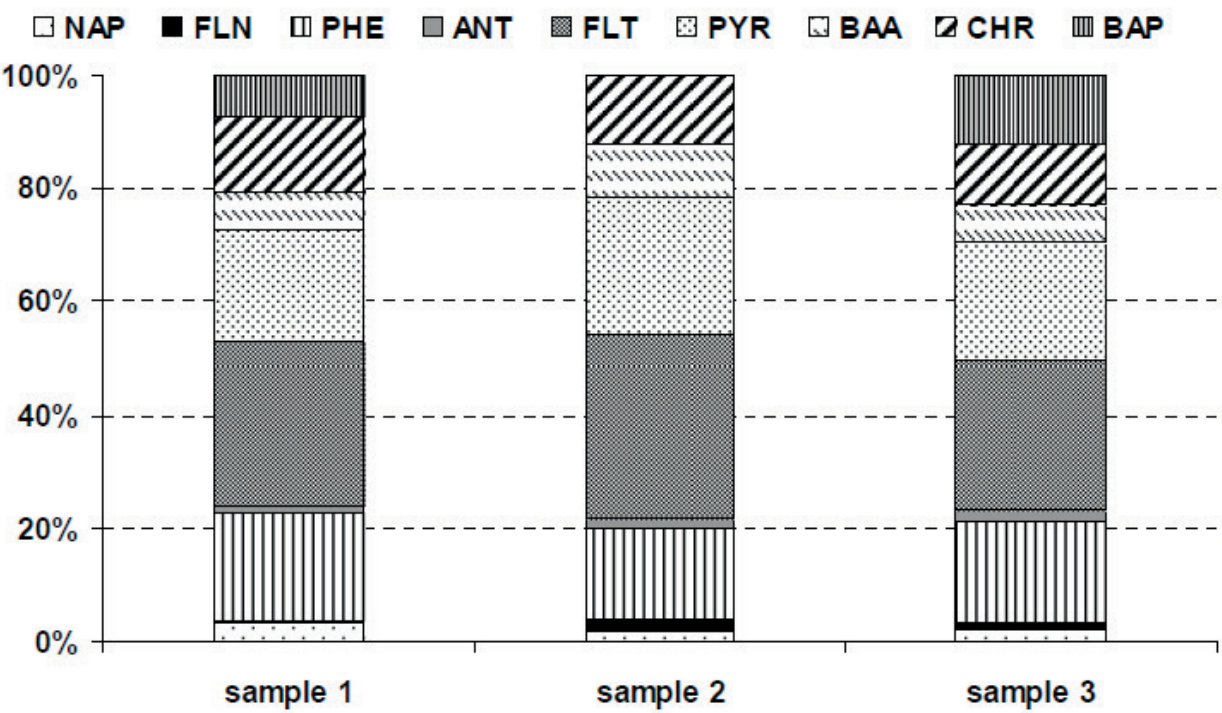

Fig. 4. Percent share of individual PAHs in their $\sum_{9} P A H s$ in the bottom sediment

Table 3

Content of PAHs in the bottom sediment

\begin{tabular}{|c|c|c|c|c|c|c|c|c|c|c|}
\hline \multirow{2}{*}{ Bottom sediment } & NAP & FLN & PHE & ANT & FLT & PYR & BAA & CHR & BAP & $\Sigma_{9} \mathrm{PAHs}$ \\
\hline & \multicolumn{10}{|c|}{ 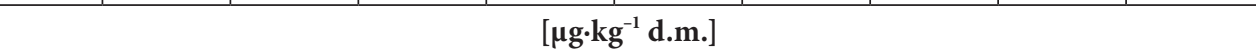 } \\
\hline Inlet - 1 & $\begin{array}{l}880 \\
\pm 39\end{array}$ & $\begin{array}{l}170 \\
\pm 40\end{array}$ & $\begin{array}{r}5310 \\
\pm 200\end{array}$ & $\begin{array}{l}320 \\
\pm 46\end{array}$ & $\begin{array}{l}8120 \\
\pm 700\end{array}$ & $\begin{array}{c}5500 \\
\pm 88\end{array}$ & $\begin{array}{l}1820 \\
\pm 173\end{array}$ & $\begin{array}{l}3730 \\
\pm 122\end{array}$ & $\begin{array}{r}2080 \\
\pm 265\end{array}$ & 27,930 \\
\hline Middle - 2 & $\begin{array}{l}250 \\
\pm 43\end{array}$ & $\begin{array}{r}280 \\
\pm 32\end{array}$ & $\begin{array}{r}2090 \\
\pm 102\end{array}$ & $\begin{array}{l}280 \\
\pm 61\end{array}$ & $\begin{array}{l}4300 \\
\pm 155\end{array}$ & $\begin{array}{c}3230 \\
\pm 88\end{array}$ & $\begin{array}{c}1210 \\
\pm 89\end{array}$ & $\begin{array}{l}1610 \\
\pm 67\end{array}$ & n.d & 13,258 \\
\hline Outlet -3 & $\begin{array}{l}770 \\
\pm 28\end{array}$ & $\begin{array}{l}320 \\
\pm 34\end{array}$ & $\begin{array}{r}6180 \\
\pm 153\end{array}$ & $\begin{array}{l}640 \\
\pm 83\end{array}$ & $\begin{array}{c}9000 \\
\pm 22\end{array}$ & $\begin{array}{c}6980 \\
\pm 76\end{array}$ & $\begin{array}{c}2210 \\
\pm 74\end{array}$ & $\begin{array}{l}3710 \\
\pm 243\end{array}$ & $\begin{array}{r}4080 \\
\pm 169\end{array}$ & 33,900 \\
\hline
\end{tabular}

n.d. - not detected. 
The lowest content of PAHs was found for ANT, FLN and NAP. The sources of PAHs can be divided into petrogenic and pyrogenic (Wang et al. 2013). Generally, petrogenic PAHs show the predominance of 2- and 3-ring PAHs, whereas pyrogenic PAHs are characterized by a high proportion of the above 4-ring PAHs. In the bottom sediment from the Rybnik reservoir, 4-ring PAHs were predominant. These compounds (FLT, PYR, BAA, CHR) constituted from $65 \%$ (inlet - 1) to $78 \%$ (middle - 2) of the $\sum_{9}$ PAHs. Pyrogenic PAHs are characteristic for incomplete combustion of organic compounds, such as fossil fuels (heating oil, coal, grass, and wood combustion, vehicle emissions, waste tires) (Tavakoly Sany et al. 2014, Wang et al. 2016). A detailed description of PAHs content in the sediments from the Rybnik reservoir has been presented in a previous study (Baran et al. 2017).

It should be noted that the reservoir is located in one of the most industrialized areas of Poland (the Upper Silesian District), which affects the contamination of the sediments. The sources of sediment contamination in the reservoir include: treated industrial sewage emitted by the Rybnik power plant, municipal sewage, rain wastewaters, sewage from the water treatment plant, cooling tower blowdowns, and dry precipitation (Baran et al. 2016). The high content of copper in the middle part of sediments (middle - 2) is probably connected with the eluting copper from the Rybnik power plant cooling system. Bojakowska \& Krasuska (2014) also observed that the copper pollution of bottom sediments of another water reservoir (Gosławskie, Licheńskie, Pątnowskie, Ślesińskie) near Konin is caused by passing the water through the Konin-Pątnów power plant cooling system. The inflow of heated water from the power plant to the middle part of the reservoir influences the increased solubility of heavy metals in sediments and affects the transformation of PAHs and organic matter. The highest solubility of metals in $1 \mathrm{~mol} \cdot \mathrm{dm}^{-3} \mathrm{HCl}$ and the lowest content of $\mathrm{C}$ organic and PAHs was demonstrated in sample 2 (middle - 2) (Tabs. 1, 3, Fig. 2). Moreover, as demonstrated by the other research, the content of individual metals in sediments increases from the coarsest to the finest fraction (Aleksander-Kwaterczak 2007). The results obtained for the Rybnik reservoir bottom sediments did not confirm the above relationship. The typical phenomenon of granular segregation which is encountered in other reservoirs does not occur in the Rybnik reservoir. Due to disturbances in the hydrodynamic processes in the reservoir, it may be presumed that geochemical relationships between the metals and PAHs, as well as the granulometric composition of the sediments from this reservoir, are disturbed.

The content of clay fraction and the content of organic matter are the key factors of the capacity of bottom sediments to accumulate metals (Farkas et al. 2007, Shaheen \& Rinklebe 2014). Organic matter has a high capacity to complex and adsorbed cations due to the presence of numerous negatively charged groups. Other factors that influence the mobility of heavy metals in sediment are: salinity, presence of sulfur, carbonates, $\mathrm{pH}$ (Du Laing et al. 2009). Organic matter is also a very important factor in the sorption process of hydrophobic organic pollutants, such as PAHs (Simson et al. 2005, Yang et al. 2016). Klimkowicz-Pawlas (2009) states that not only the content of organic matter, but also its qualitive composition, are important in the sorption process of PAHs. The highest sorption capability in relation to PAHs is exhibited by humins, a significantly lower capability is exhibited by humic acids, and the lowest one by fulvic acids (Klimkowicz-Pawlas 2009). Moreover, an important role in the sorption process of PAHs is played by organic matter of organic origin, the so-called black carbon. Black carbon exhibits 10-1000 times stronger sorption properties in relation to $\mathrm{PAHs}$ than humic or fulvic acids (Cornelissena et al. 2006, Klimkowicz-Pawlas 2009, Ukalska-Jurga et al. 2015). Black carbon includes substances created in the process of pyrolysis and/or incomplete combustion of biomass or fossil fuels, and these include: kerogen, charcoal, charred plant matter, soot, graphite and ash (Ukalska-Jurga et al. 2015). We assume that this fraction of organic matter may be of significant importance in the sorption of organic pollutants in the bottom sediments of the Rybnik reservoir.

To sum up, organic matter is an important parameter determining the transport and fate of inorganic and organic pollutants. Many authors have found that organic matter has a great complexing ability of heavy metals and PAHs in bottom sediments (Dahle et al. 2003, Raposo et al. 2016, 
Wu et al. 2016, Baran et al. 2017). Moreover, humic substances have a variety of functional groups and can form strong complexes with metal ions, affecting their mobilization and toxicity (Hou et al. 2014). In our studies, a high organic matter content in the samples of outlet -3 and inlet -1 as well as high total contents of heavy metals and $\mathrm{PAH}_{\mathrm{S}}$ in those sediments demonstrate that these pollutants have a strong affinity for organic matter in the sediments collected from the Rybnik reservoir. Moreover, we think that the higher solubility of metals extracted in $1 \mathrm{~mol} \cdot \mathrm{dm}^{-3} \mathrm{HCl}$ form samples 2 (middle) is connected with a low content of organic matter, the low buffer capacities of sediments as well as the inflow of heated water from the power plant to the middle part of the reservoir.

\section{CONCLUSION}

1. The highest content of $\mathrm{C}$ organic, $\mathrm{C}$ extracted, Cha, Cfa and Cnh was found in sample 3 (outlet, near the dam), while the lowest content was found in sample 2 (middle).

2. The fraction of $\mathrm{Cnh}$ was dominated in the sediment sample 3 (outlet, near the dam) and 1 (inlet), whereas the fraction of Cha was dominated in sample 2 (middle).

3. Rybnik bottom sediments are characterized by high buffer capacities (samples 3,1 ), among others, shaped by a high content of organic matter.

4. The contents of heavy metals and PAHs in sediments demonstrate that these pollutants have a good affinity for organic matter in the Rybnik reservoir sediments.

5. However, it is necessary to perform other studies, such as the determinations of black carbon and the content of metals and PAHs in the tissues of benthic organisms and fish, because the Rybnik reservoir is used for fishing and recreational purposes on a large scale. It is also important to increase the number of bottom sediment samples for the analysis.

The study was financed by grant no. 2016/21/B/ ST10/02127 "Assessment of the bottom sediment organic matter on bioavailability and toxicity of chemical compounds" provided by the National Science Centre, Poland.

\section{REFERENCES}

Aleksander-Kwaterczak U., 2007. Rozmieszczenie metali śladowych $w$ rdzeniach osadów wybranych rzek Polski. Uczelniane Wydawnictwa Naukowo-Dydaktyczne AGH, Kraków.

Baran A., Tarnawski M. \& Kaczmarski M., 2011a. Assessment of agricultural utilization of bottom sediment from the Besko Reservoir. Czasopismo Techniczne, 1-Ch, $8,108,23-11$.

Baran A., Tarnawski M. \& Jasiewicz C., 2011b. Assessment of the content and solubility of heavy metals in bottom sediments of Chancza reservoir. Ecological Chemistry and Engineering A, 18, 7, 941-950.

Baran A., Tarnawski M. \& Koniarz T., 2016. Spatial distribution of trace elements and ecotoxicity of bottom sediments in Rybnik reservoir, Silesian-Poland. Environmental Science and Pollution Research, 23, 17, 17255-17268.

Baran A., Tarnawski M., Urbański K., Klimkowicz-Pawlas A. \& Spałek I., 2017. Concentration, sources and risk assessment of PAHs in bottom sediments. Environmental Science and Pollution Research, 24, 29, 23180-23195.

Boháček Z., Bezděk J., Kovářová M., Hanák J., Toul J. \& Müller., 2003. Characteristics of organic matter and contents of some ubiquitous hydrophobic organic Pollutants in selected soils and sediments. Bulletin of Geosciences, $78,3,179-204$.

Bojakowska I. \& Krasuska J., 2014. Copper and other trace elements in sediments of lake near Konin (Poland). Journal of Elementology, 19(1), 31-40.

Cornelissen G., Gustafsson O., Bucheli T., Jonker M., Koelmans A. \& van Noort P., 2005. Extensive sorption of organic compounds to black carbon, coal, and kerogen in sediments and soils: mechanisms and consequences for distribution, bioaccumulation, and biodegradation. Environmental Science and Technology, 39, 6881-6895.

Dahle S., Savinov V., Matishov G., Evenset A. \& Neas K., 2003. Polycyclic aromatic hydrocarbons (PAHs) in bottom sediments of the Kara Sea shelf, Gulf of $\mathrm{Ob}$ and Yenisei Bay. The Science of The Total Environment, 306, 57-71.

Du Laing G., Rinklebe J., Vandecasteele B., Meers E. \& Tack F.M.G., 2009. Trace metal behaviour in estuarine and riverine floodplain soils and sediments: A review. Science of Total Environment, 407, 3972-3985.

Farkas A., Erratico C. \& Vigano L., 2007. Assessment of the environmental significance of heavy metal pollution in surficial sediments of the River Po. Chemosphere, 68, 761-768.

Giovanela M. et al., 2010. Chemical and spectroscopic characterization of humic acids extracted from the bottom sediments of a Brazilian subtropical microbasin. Journal of Molecular Structure, 981, 1-3, 111-119.

Gondek K. \& Kopeć M., 2006. Heavy metal binding by organic substance in sewage sludge of various origins. Electronic Journal of Polish Agricultural Universities, 9(3), [on-line:] http/ejpau.media.pl/volume9/issue3/art-01.html [access: 22.11.2017].

Gondek K. \& Mierzwa M., 2014. Quantity and quality of organic matter in soil after application of various organic materials. Ecological, Chemistry and Engineering S, 21, 3, 477-485. 
Hou D., He J., Lü Ch., Wang W. \& Zhang F., 2014. Spatial distributions of humic substances and evaluation of sediment organic index on lake Dalinouer, China. Journal of Geochemistry, [on-line:] http://dx.doi.org/ 10.1155/2014/502597 [access: 26.11.2017].

Kononowa M., 1968. Substancje organiczne gleby, ich budowa, właściwości i metody badań. PWRiL, Warszawa.

Klimkowicz-Pawlas A., 2009. Oddziaływanie wielopierścieniowych wegglowodorów aromatycznych na siedliskowa funkcję gleby. Monografie i Rozprawy Naukowe - Instytut Uprawy, Nawożenia i Gleboznawstwa, 22, Instytut Uprawy Nawożenia i Gleboznawstwa - Państwowy Instytut Badawczy, Puławy.

López D.L., Gierlowski-Kordesch E. \& Hollenkamp C., 2010. Eochemical mobility and bioavailability of heavy metals in a lake affected by acid mine drainage: Lake Hope, Vinton County, Ohio. Water, Air and Soil Pollution, 213, 27-45.

Maliszewska-Kordybach B., Klimkowicz-Pawlas A. \& Smreczak B., 2010. Relationship between the properties of mineral soils and the level of accumulation of persistent organic contaminants; example of polycyclic aromatic hydrocarbons. [in:] Szajdak L.W. \& Karabanov A.K. (eds.), Physical, Chemical and Biological Process in Soils, The Committee on Land Reclamation and Agricultural Environment Engineering, Polish Academy of Science, Poznań, 345-358

Mamontova E.A, Mamontov A.A. \& Tarasova E.N., 2016. Polychlorinated biphenyls and organochlorine pesticides in bottom sediments of the Irkutsk Reservoir. $\mathrm{Wa}$ ter Quality and Protection, 43, 2, 335-340.

Mengchang H.E., Yehong S.H.I. \& Chunye L.I.N., 2008. Characterization of humic acids extracted from the sediments of the various rivers and lakes in China. Journal of Environmental Sciences, 20, 1294-1299.

Morales J., Manso J., Cid A. \& Mejuto J.C., 2012. Degradation of carbofuran and carbofuran-derivatives in presence of humic substances under basic conditions. Chemosphere, $89,1267-1271$

Oleszczuk P., 2007a. Biodostępność i bioakumulacja hydrofobowych zanieczyszczeń organicznych. Cz. I. Informacje ogólne. Biotechnologia, 1(76), 9-25.

Oleszczuk P., 2007b. Biodostępność i bioakumulacja hydrofobowych zanieczyszczeń organicznych. Cz. II. Sorpcja zanieczyszczeń oraz czynniki wpływające na ten proces. Biotechnologia, 1(76), 26-39.

Raposo J., Villanueva U., Olivares M. \& Madariaga M.J., 2016. Determination of humic substances in sediments by focused ultrasound extraction and ultraviolet visible spectroscopy. Microchemical Journal, 128, 26-33.
Shaheen, S.M. \& Rinklebe J., 2014. Geochemical fractions of chromium, copper, and zinc and their vertical distribution in floodplain soil profiles along the Central Elbe. Geoderma, 228-229, 152-159.

Simpson M., Chefetz B., Deshmukh A. \& Hatcher P., 2005. Comparison of polycyclic aromatic hydrocarbon distributions and sedimentary organic matter characteristics in contaminated, coastal sediments from Pensacola Bay, Florida. Marine Environmental Research, 59, 139-163.

Szarek-Gwiazda E., 2014, Potential effect of pH on the leaching of heavy metals from sediments of the Carpathian dam reservoirs. Geology, Geophysics \& Environment, 40, 4, 349-358.

Tavakoly Sany S.B., Hashim R., Salleh A., Rezayi M., Mehdinia A. \& Safari O., 2014. Polycyclic aromatic hydrocarbons in coastal sediment of Klang Strait, Malaysia: distribution pattern, risk assessment and sources. Plos One, 9, e94907.

Tuikka A.I., Schmitt C., Höss S. et al., 2011. Toxicity assessment of sediments from three European river basins using a sediment contact test battery. Ecotoxicology and Environmental Safety, 74, 123-131.

Ukalska-Jaruga A., Smreczak B., Klimkowicz-Pawlas A. \& Maliszewska-Kordybach B., 2015. Rola materii organicznej w procesach akumulacji trwałych zanieczyszczeń organicznych (TZO) w glebach. Polish Journal of Agrono$m y, 20,15-23$.

Urbaniak M., Zieliński M. \& Wagner I., 2015. Seasonal distribution of PCDDs/PCDFs in the small urban reservoirs. International Journal of Environmental Research, $9,2,745-752$.

Wang Ch., Zou X., Zhao Y., Li B., Song Q., Li Y., \& Yu W., 2016. Distribution, sources and ecological risk assessment of polycyclic aromatic hydrocarbons in the water and suspended sediments from the middle and lower reaches of the Yangtze River, China. Environmental Science and Pollution Research, 23, 17158-17170.

Wang X-T., Miao Y., Zhang Y., Li Y-Ch., Wu M-H. \& Yu G., 2013. Polycyclic aromatic hydrocarbons (PAHs) in urban soils of the megacity Shanghai: occurrence, source apportionment and potential human health risk. Science of the Total Environment, 447, 80-89.

Wu Ch., Bao L-J, Tao S. \& Zeng E., 2016. Mediated distribution pattern of organic compounds in estuarine sediment by anthropogenic debris. Science of the Total Environment, 565, 132-139.

Yang X., Liuqian Y., Zefang Ch. \& Meiying Xu., 2016. Bioavailability of Polycyclic Aromatic Hydrocarbons and their Potential Application in Eco-risk Assessment and Source Apportionment in Urban River Sediment. Scientific Reports, 6, 23134. 